Pol. J. Food Nutr. Sci., 2020, Vol. 70, No. 2, pp. 151-157

DOI: $10.31883 /$ pjfns/116395 http://journal.pan.olsztyn.pl

Original article

Section: Food Technology

\title{
Co-Cultivation Growth of Escherichia coli and Staphylococcus aureus as Two Common Dairy Contaminants
}

\author{
Alžbeta Medvedová*, Romana Györiová, Veronika Lehotová, Lubomír Valík \\ Department of Nutrition and Food Quality Assessment, Faculty of Chemical and Food Technology, \\ Slovak University of Technology, Bratislava, Radlinského 9, 81237 Bratislava, Slovakia
}

Key words: predictive microbiology, growth parameters, microbial interactions, E. coli, S. aureus

The overgrowth of spoilage and pathogenic bacteria may pose risk to consumers health and cause technological and economic losses. Hence, interactions among S. aureus 2064 and $E$. coli BR in dependence of incubation temperature and different initial counts of both microorganisms were quantitatively described based on cultivation experiments and predictive models. Statistically insignificant differences ( $\mathrm{p} \geq 0.05)$ between growth rates of $E$. coli at different initial concentrations suggest that the growth rates of $E$. coli in co-cultivation with $S$. aureus were affected only by incubation temperature. The growth of $E$. coli can be reliably predicted $\left(R^{2}=0.968 ; A_{\mathrm{f}}=1.160\right)$ based on the equation $\sqrt{\mu}=0.0283(T-T$ in $)+0.1038$. The growth of $S$. aureus during its co-cultivation with $E$. coli was influenced by incubation temperature and the presence of $E$. coli as well. It was documented by relatively high discrepancies indexes $\left(D_{\mathrm{f}} 23.9-43.9 \%\right)$ and also by differences between growth rates at different initial microbial concentrations. These results may help in better understanding of interrelationships during sensitive foods production (e.g. without temperature treatment or those with intensive manual handling).

\section{INTRODUCTION}

The trend for the consumption of raw milk and raw milk products, in the context of "consuming natural" and "purchasing locally" is becoming more and more popular. Taking into account the high nutritious potential of raw milk demonstrated by the presence of various macronutrients (carbohydrates, fats and proteins with easy digestibility), micronutrients (vitamins and minerals), regulators of physiological processes (amino acids), almost neutral $\mathrm{pH}$ (6.4-6.7), and high water activity [Claeys et al., 2013; Hahne et al., 2019], it is a valuable food not only for human and animals, but also for microorganisms. The sources of microbial contaminants are versatile, including the animal udder surface, feed, feces, milking equipment [Quigley et al., 2013] or contact with milk handling personnel [Valík, 2013]. Besides technologically important bacteria (e.g. lactic acid bacteria LAB), accompanying species (e.g. Micrococcus) also spoilage and pathogenic bacteria may occur. The presence of spoilage bacteria can have considerable negative effects on the quality of milk and dairy products, the presence of pathogens can have more severe repercussions [Quigley et al., 2011; Valík, 2013]. Hence, the risk posed by consuming raw milk, whether due to the rare presence of such pathogenic bacteria that cause severe disease with high mortality rates (e.g. Listeria monocytogenes) or due

\footnotetext{
* Corresponding Author: Tel.: 004212 59325524;

E-mail: alzbeta.medvedova@stuba.sk (A. Medvedová)
}

to frequently occurring bacteria with low severity (e.g. Campylobacter spp., Staphylococcus aureus or Escherichia coli) is still considered high [Valík, 2013].

In our work, we focused on two bacteria: E. coli and S. aureus, considering their frequent presence in milk and in the environment (raw materials of animal and plant origin, feed, handling personnel, but also wastewater or sludge that can be reused as fertilizer in agricultural soil), their good growth in different nutrient media, genetic properties, and severity of causing diseases. Their growth, survival, and formation of harmful metabolites are dependent not only on the quantity they achieve in the media, but also on conditions of the surrounding environment and also on their mutual interactions. If the environmental conditions create a favorable growth environment, these hygienically and technologically undesirable microorganisms can multiply, produce toxic metabolites, and ultimately endanger the health of consumers [Medvedová \& Valík, 2012]. Therefore it is necessary to determine relationships between microorganisms themselves and also between microorganisms and external and internal environmental factors that determine microbial growth, or lead to their inhibition. This is also the main role and contribution of predictive microbiology. Thus, if we obtain a mathematical equation describing the impact of environmental conditions on the behavior of microorganisms in food, it is natural to use such knowledge and quantify (predict) the extent and degree of their impact on microbiological quality and food safety [Ross \& McMeekin, 1994]. Additionally, in specific cases, 
mathematical modelling is also required to predict the interaction of antagonist or competitively behaving populations [Vereecken et al., 2000; Brocklehurst et al., 2004; Giménez \& Dalgaard, 2004; Valík \& Ačai, 2016].

In this context, the aim of our work was to quantitatively describe the mutual relationships between these potentially pathogenic bacteria in dependence on incubation temperature and proportion of their initial counts that can have impact on which population will be dominating in a given environment, even if the initial counts of one of the population will be unusually high or above the legislative limits.

\section{MATERIAL AND METHODS}

\section{Bacterial isolates}

The isolate of $E$. coli BR was isolated from a Slovakian traditional "Bryndza" cheese. The isolate of $S$. aureus 2064 was isolated from a Slovakian ewes' lump cheese. Both isolates were maintained in Brain Hearth Infusion (BHI) broth (Sigma-Aldrich, St. Louis, Missouri, USA) at $5 \pm 0.5^{\circ} \mathrm{C}$ prior to analysis. Their identity was confirmed and described in our previous work [Medvedová et al., 2009, 2018].

\section{Inoculation, cultivation conditions, and bacterial counts enumeration}

A standard suspension of each isolate was prepared from a 24-h old culture grown in BHI broth at $37^{\circ} \mathrm{C}$. These cultures were then diluted in saline-peptone solution and from $10^{-3}$ dilution $0.3 \mathrm{~mL}$ were inoculated into $300 \mathrm{~mL}$ of pre-tempered ultra/high temperature treated (UHT) milk (Rajo, Bratislava, Slovakia). The nutritional composition of $100 \mathrm{~mL}$ of UHT milk was as follows: $1.5 \mathrm{~g}$ of fat, from which $0.9 \mathrm{~g}$ were saturated fatty acids, $3.4 \mathrm{~g}$ of proteins, and $4.9 \mathrm{~g}$ of sugars from which $4.9 \mathrm{~g}$ was lactose. The above inoculation procedure was aimed to reach initial concentration of $E$. coli at approximately $10^{3} \mathrm{CFU} / \mathrm{mL}$ and of $S$. aureus at approximately $10^{6} \mathrm{CFU} / \mathrm{mL}(3 \mathrm{EC}+6 \mathrm{STA})$; of E. coli at approximately $10^{6} \mathrm{CFU} / \mathrm{mL}$ and of $S$. aureus at approximately $10^{3} \mathrm{CFU} / \mathrm{mL}(6 \mathrm{EC}+3 \mathrm{STA})$; of $E$. coli at approximately $10^{3} \mathrm{CFU} / \mathrm{mL}$ and of $S$. aureus at approximately $10^{3} \mathrm{CFU} / \mathrm{mL}(3 \mathrm{EC}+3 \mathrm{STA})$. The static incubation of three parallel and three replicates experiments was performed at $6,12,15,18,21,25,30$, and $37 \pm 0.5^{\circ} \mathrm{C}$.

Sampling was performed at predefined time intervals taking into account the incubation temperature, to reach the best possible fit of model in curvature between lag phase and exponential phase and then between exponential phase and stationary phase. We took into account data obtained during monocultural growth of the isolates. Actual density of the studied isolates was determined by 10 -fold dilution in a saline-peptone solution and by using selective nutrient media, Baird-Parker agar (Merck, Darmstadt, Germany) for determination of $S$. aureus 2064 counts according to EN ISO 6888-1 and Chromocult Coliform agar (Merck, Darmstadt, Germany) for determination of $E$. coli BR counts according to National Standard Method F23. At the same time as microbial density was determined, also a $\mathrm{pH}$ value of the media was examined by using a WTW Inolab 720 pH meter (Weilheim, Germany).

\section{Modelling the microbial growth}

Growth parameters from each individual growth curves for both microbial isolates were determined by using a primary model of Baranyi \& Roberts [1994] using an in-house Excel Add-in package 'DMFit' version 3.5 (ComBase managed by United States Department of Agriculture-Agricultural Research Service, Washington, USA; and University of Tasmania Food Safety Centre, Hobart, Australia). Subsequently, the effect of temperature on the growth rates was described by the model of Ratkowsky et al. [1982]:

$$
\sqrt{\mu_{\max }}=b\left(T-T_{\min }\right)
$$

where: $\mu_{\max }$ is specific growth rate $(1 / \mathrm{h}), T$ is actual incubation temperature, $T_{\min }$ is theoretical minimum temperature at which growth was observed $\left({ }^{\circ} \mathrm{C}\right)$, and $b$ is a Ratkowsky parameter [Ross \& McMeekin, 1994; Valík \& Ačai, 2016].

\section{Validation and statistical analysis}

To validate mathematical equations describing the temperature effect on the growth rate of the isolates, the accuracy $(A f)$, bias $(B f)$, and discrepancy $(\% D f)$ factors were used as defined by Baranyi et al. [1999]. Also the ordinary least-squares criterion and regression coefficient $\left(R^{2}\right)$ were used. Finally, the statistical analysis (independent Student $t$-test and ANOVA test with statistical significance of $\mathrm{p}<0.05$ ) was performed using Microsoft Excel tools 2007 (Microsoft, Redmond, USA).

\section{RESULTS AND DISCUSSION}

Microbial interactions have been described intensively and also several predictive models have been introduced by e.g. Giménez \& Dalgaard [2004], Vereecken et al. [2000] or Brocklehurst et al. [2004]. However, all these models focused on the competition or antagonistic behavior of LAB on the growth of spoilage or pathogenic bacteria, as we described also earlier in Valík et al. [2018] for S. aureus in dependence of LAB and in Ačai et al. [2016] for E. coli mutual growth with LAB. However, in this paper we would like to draw the attention to the interactions between spoilage/pathogenic bacteria themselves, since $S$. aureus and E. coli are frequently present in raw materials [Quigley et al., 2013], in which they can multiply until concentrations resulting in disease outbreaks [Medvedová \& Valík, 2012]. Their growth is affected not only by environmental conditions but also by the present microbiota, the pathogenic one included.

The initial concentration of $E$. coli in experiments with $6 \mathrm{EC}$ was $N_{0 \mathrm{EC}}=6.11 \pm 0.19 \log \mathrm{CFU} / \mathrm{mL}(\mathrm{n}=24 ; \mathrm{cv}=3.1 \%)$, and in experiments with $3 \mathrm{EC}$ it was $N_{0 \mathrm{EC}}=3.27 \pm 0.32 \mathrm{log}$ $\mathrm{CFU} / \mathrm{mL} \quad(\mathrm{n}=48 ; \mathrm{cv}=9.9 \%)$. On the other hand, initial counts of $S$. aureus in experiments with 6 STA was $N_{\text {OSTA }}=5.98 \pm 0.21 \log \mathrm{CFU} / \mathrm{mL} \quad(\mathrm{n}=24 ; \mathrm{cv}=3.5 \%)$ and in experiments with 3 STA it was $N_{0 \mathrm{STA}}=3.40 \pm 0.61 \log \mathrm{CFU} /$ $\mathrm{mL}(\mathrm{n}=48 ; \mathrm{cv}=17.9 \%)$.

The growth of both microbial partners was positively affected by increased incubation temperature as it is also shown by growth parameters calculated by the model of Baranyi \& Roberts [1994] summarized in Table 1. Exemplary 
TABLE 1. Growth parameters of E. coli (EC) BR and S. aureus (STA) 2064 during their co-cultivation in UHT milk in dependence of temperature and parameters of $\mathrm{pH}$ value change.

\begin{tabular}{|c|c|c|c|c|c|c|c|c|}
\hline \multirow{2}{*}{$\begin{array}{l}\text { Experimental } \\
\text { variant }\end{array}$} & \multicolumn{2}{|c|}{$\mu$} & \multicolumn{2}{|c|}{ lag } & \multicolumn{2}{|c|}{$N_{\max }$} & \multicolumn{2}{|c|}{$p H$} \\
\hline & S. aureus & E. coli & S. aureus & E. coli & S. aureus & E. coli & $k$ & $\operatorname{lag}_{\mathrm{pH}}$ \\
\hline \multicolumn{9}{|c|}{ Temperature $6^{\circ} \mathrm{C}$} \\
\hline $3 \mathrm{STA}+3 \mathrm{EC}$ & $0.02 \pm 0.00$ & $-0.01 \pm 0.00$ & $138.3 \pm 3.9$ & $0 \pm 0.0$ & $5.11 \pm 0.06$ & $1.25 \pm 0.07$ & $-0.01 \pm 0.00$ & $0 \pm 0.0$ \\
\hline $3 \mathrm{STA}+6 \mathrm{EC}$ & $0.12^{* \mathrm{a}} \pm 0.02$ & $-0.01 \pm 0.00$ & $226.6^{* a} \pm 27.3$ & $0 \pm 0.0$ & $3.50^{* \mathrm{a}} \pm 0.14$ & $3.91^{\mathrm{a}} \pm 0.09$ & $-0.01 \pm 0.00$ & $0 \pm 0.0$ \\
\hline $6 \mathrm{STA}+3 \mathrm{EC}$ & $0.01^{\mathrm{c}} \pm 0.00$ & $-0.01 \pm 0.00$ & $0^{\mathrm{b}, \mathrm{c}} \pm 0.0$ & $35.9^{\mathrm{b}, \mathrm{c}} \pm 14.6$ & $6.03^{\mathrm{b}, \mathrm{c}} \pm 0.17$ & $0.97^{\mathrm{b}, \mathrm{c}} \pm 0.05$ & $-0.01 \pm 0.00$ & $300.4 \pm 5.4$ \\
\hline \multicolumn{9}{|c|}{ Temperature $12^{\circ} \mathrm{C}$} \\
\hline $3 \mathrm{STA}+3 \mathrm{EC}$ & $0.10 \pm 0.01$ & $0.14 \pm 0.00$ & $23.9 \pm 0.7$ & $21.0 \pm 0.6$ & $8.08 \pm 0.06$ & $8.65 \pm 0.04$ & $-0.22 \pm 0.02$ & $128.8 \pm 2.4$ \\
\hline $3 \mathrm{STA}+6 \mathrm{EC}$ & $0.51^{\mathrm{a}} \pm 0.02$ & $0.13 \pm 0.00$ & $121.7^{\mathrm{a}} \pm 0.3$ & $18.7^{\mathrm{a}} \pm 0.2$ & $8.07 \pm 0.31$ & $8.72 \pm 0.02$ & $-0.03 \pm 0.01$ & $130.4 \pm 3.5$ \\
\hline $6 \mathrm{STA}+3 \mathrm{EC}$ & $0.12^{\mathrm{c}} \pm 0.02$ & $0.14 \pm 0.00$ & $75.2^{\mathrm{b}, \mathrm{c}} \pm 7.7$ & $19.9 \pm 1.9$ & $7.99^{\mathrm{b}, \mathrm{c}} \pm 0.02$ & $8.70 \pm 0.06$ & $-0.01 \pm 0.00$ & $0 \pm 0.0$ \\
\hline \multicolumn{9}{|c|}{ Temperature $15^{\circ} \mathrm{C}$} \\
\hline $3 \mathrm{STA}+3 \mathrm{EC}$ & $0.30 \pm 0.00$ & $0.31 \pm 0.01$ & $15.0 \pm 0.2$ & $5.5 \pm 1.6$ & $8.54 \pm 0.01$ & $8.85 \pm 0.04$ & $-0.26 \pm 0.02$ & $44.9 \pm 2.4$ \\
\hline $3 \mathrm{STA}+6 \mathrm{EC}$ & $0.01^{\mathrm{a}} \pm 0.00$ & $0.21^{\mathrm{a}} \pm 0.00$ & $64.1^{\mathrm{a}} \pm 27.9$ & $6.6 \pm 1.2$ & $3.67^{\mathrm{a}} \pm 0.07$ & $8.62^{\mathrm{a}} \pm 0.03$ & $-0.07 \pm 0.01$ & $24.2 \pm 1.6$ \\
\hline $6 \mathrm{STA}+3 \mathrm{EC}$ & $0.30^{\mathrm{c}} \pm 0.01$ & $0.21^{\mathrm{b}} \pm 0.00$ & $16.5^{\mathrm{b}, \mathrm{c}} \pm 1.5$ & $3.8^{\mathrm{b}, \mathrm{c}} \pm 1.1$ & $8.69^{\mathrm{b}, \mathrm{c}} \pm 0.06$ & $8.55^{\mathrm{b}} \pm 0.00$ & $-0.06 \pm 0.01$ & $21.9 \pm 2.1$ \\
\hline \multicolumn{9}{|c|}{ Temperature $18^{\circ} \mathrm{C}$} \\
\hline $3 \mathrm{STA}+3 \mathrm{EC}$ & $0.31 \pm 0.00$ & $0.35 \pm 0.02$ & $2.5 \pm 0.8$ & $5.2 \pm 1.1$ & $7.88 \pm 0.03$ & $8.26 \pm 0.14$ & $-0.05 \pm 0.01$ & $25.1 \pm 2.5$ \\
\hline $3 \mathrm{STA}+6 \mathrm{EC}$ & $0.10^{\mathrm{a}} \pm 0.00$ & $0.29^{\mathrm{a}} \pm 0.01$ & $17.9^{\mathrm{a}} \pm 0.2$ & $4.6 \pm 0.6$ & $4.85^{\mathrm{a}} \pm 0.00$ & $8.62^{\mathrm{a}} \pm 0.06$ & $-0.44 \pm 0.08$ & $19.3 \pm 1.8$ \\
\hline $6 \mathrm{STA}+3 \mathrm{EC}$ & $0.26^{\mathrm{b}, \mathrm{c}} \pm 0.00$ & $0.41^{\mathrm{c}} \pm 0.01$ & $2.8^{c} \pm 0.3$ & $7.5^{\mathrm{c}} \pm 0.0$ & $8.38^{\mathrm{b}, \mathrm{c}} \pm 0.08$ & $6.71^{\mathrm{b}, \mathrm{c}} \pm 0.00$ & $-0.14 \pm 0.04$ & $15.9 \pm 1.9$ \\
\hline \multicolumn{9}{|c|}{ Temperature $21^{\circ} \mathrm{C}$} \\
\hline $3 \mathrm{STA}+3 \mathrm{EC}$ & $0.47 \pm 0.01$ & $0.64 \pm 0.01$ & $1.8 \pm 0.0$ & $3.7 \pm 2.3$ & $8.47 \pm 0.01$ & $8.81 \pm 0.03$ & $-0.49 \pm 0.12$ & $27.2 \pm 5.4$ \\
\hline $3 \mathrm{STA}+6 \mathrm{EC}$ & $1.40^{\mathrm{a}} \pm 0.39$ & $0.65 \pm 0.00$ & $7.7 \pm 4.4$ & $3.9 \pm 0.1$ & $4.76^{\mathrm{a}} \pm 0.05$ & $8.99^{a} \pm 0.00$ & $-0.10 \pm 0.01$ & $23.7 \pm 4.8$ \\
\hline $6 \mathrm{STA}+3 \mathrm{EC}$ & $0.69^{\mathrm{b}, \mathrm{c}} \pm 0.01$ & $0.55^{b, c} \pm 0.02$ & $2.9 \pm 0.1$ & $2.2 \pm 1.7$ & $8.82^{\mathrm{b}, \mathrm{c}} \pm 0.01$ & $8.58^{\mathrm{b}, \mathrm{c}} \pm 0.03$ & $-0.22 \pm 0.04$ & $49.2 \pm 6.9$ \\
\hline \multicolumn{9}{|c|}{ Temperature $25^{\circ} \mathrm{C}$} \\
\hline $3 \mathrm{STA}+3 \mathrm{EC}$ & $0.78 \pm 0.00$ & $1.09 \pm 0.00$ & $1.3 \pm 0.2$ & $2.0 \pm 0.1$ & $8.73 \pm 0.02$ & $9.03 \pm 0.04$ & $-0.61 \pm 0.15$ & $5.1 \pm 0.4$ \\
\hline $3 \mathrm{STA}+6 \mathrm{EC}$ & $0.05^{\mathrm{a}} \pm 0.00$ & $0.41^{\mathrm{a}} \pm 0.00$ & $0^{\mathrm{a}} \pm 0.0$ & $0^{\mathrm{a}} \pm 0.0$ & $4.89^{\mathrm{a}} \pm 0.00$ & $8.81^{\mathrm{a}} \pm 0.03$ & $-0.24 \pm 0.08$ & $9.8 \pm 1.1$ \\
\hline $6 \mathrm{STA}+3 \mathrm{EC}$ & $1.55^{\mathrm{b}, \mathrm{c}} \pm 1.26$ & $0.89^{b, c} \pm 0.01$ & $2.7^{\mathrm{b}, \mathrm{c}} \pm 0.0$ & $1.2^{b, c} \pm 0.3$ & $8.95^{\mathrm{b}, \mathrm{c}} \pm 0.04$ & $8.69^{\mathrm{b}, \mathrm{c}} \pm 0.02$ & $-0.11 \pm 0.01$ & $4.2 \pm 0.7$ \\
\hline \multicolumn{9}{|c|}{ Temperature $30^{\circ} \mathrm{C}$} \\
\hline $3 \mathrm{STA}+3 \mathrm{EC}$ & $1.03 \pm 0.01$ & $1.09 \pm 0.01$ & $1.4 \pm 0.3$ & $0.4 \pm 0.2$ & $7.47 \pm 0.06$ & $8.32 \pm 0.01$ & $-0.12 \pm 0.01$ & $8.3 \pm 1.2$ \\
\hline $3 \mathrm{STA}+6 \mathrm{EC}$ & $0.28^{\mathrm{a}} \pm 0.00$ & $1.08 \pm 0.07$ & $0^{\mathrm{a}} \pm 0.0$ & $1.2 \pm 0.8$ & $4.94^{\mathrm{a}} \pm 0.00$ & $8.91^{\mathrm{a}} \pm 0.06$ & $-0.10 \pm 0.01$ & $3.6 \pm 0.5$ \\
\hline $6 \mathrm{STA}+3 \mathrm{EC}$ & $0.86^{\mathrm{b}, \mathrm{c}} \pm 0.04$ & $1.21^{\mathrm{b}} \pm 0.01$ & $0^{\mathrm{b}} \pm 0.0$ & $0 \pm 0.0$ & $8.95^{b, c} \pm 0.02$ & $8.20^{\mathrm{b}, \mathrm{c}} \pm 0.01$ & $-0.11 \pm 0.01$ & $4.3 \pm 0.2$ \\
\hline \multicolumn{9}{|c|}{ Temperature $37^{\circ} \mathrm{C}$} \\
\hline $3 \mathrm{STA}+3 \mathrm{EC}$ & $1.43 \pm 0.01$ & $1.82 \pm 0.01$ & $0 \pm 0.0$ & $0.7 \pm 0.0$ & $8.28 \pm 0.03$ & $8.89 \pm 0.08$ & $-0.26 \pm 0.17$ & $6.9 \pm 1.5$ \\
\hline $3 \mathrm{STA}+6 \mathrm{EC}$ & $0.34^{\mathrm{a}} \pm 0.09$ & $2.06 \pm 0.12$ & $0 \pm 0.0$ & $1.1 \pm 0.0$ & $4.78^{\mathrm{a}} \pm 0.12$ & $8.78 \pm 0.01$ & $-0.42 \pm 0.21$ & $4.7 \pm 1.1$ \\
\hline $6 \mathrm{STA}+3 \mathrm{EC}$ & $0.88^{b, c} \pm 0.01$ & $2.19 \pm 0.11$ & $1.1^{\mathrm{b}, \mathrm{c}} \pm 0.3$ & $1.5 \pm 0.3$ & $8.95^{b, c} \pm 0.15$ & $8.79 \pm 0.03$ & $-0.34 \pm 0.12$ & $9.1 \pm 2.4$ \\
\hline
\end{tabular}

$\mu$ - specific growth rate (1/h), lag - duration of lag phase (h), $N_{\max }$ - counts of isolates in the stationary phase $(\log \mathrm{CFU} / \mathrm{mL}), k-$ rate of $\mathrm{pH}$ value decrease $(1 / \mathrm{h}), \operatorname{lag}_{\mathrm{pH}}$ - duration of $\mathrm{pH}$ value lag phase $(\mathrm{h}) ;{ }^{*}{ }^{*}$ - results only for the first growth phase; statistical significant differences $(p<0.05)$ within parameters ${ }^{\mathrm{a}}-$ in experiments $3 \mathrm{STA}+3 \mathrm{EC}$ and $3 \mathrm{STA}+6 \mathrm{EC},{ }^{\mathrm{b}}-$ in experiments $3 \mathrm{STA}+3 \mathrm{EC}$ and $6 \mathrm{STA}+3 \mathrm{EC},{ }^{\mathrm{c}}-$ in experiments $3 \mathrm{EC}+6 \mathrm{STA}$ and $6 \mathrm{STA}+3 \mathrm{EC}$. 

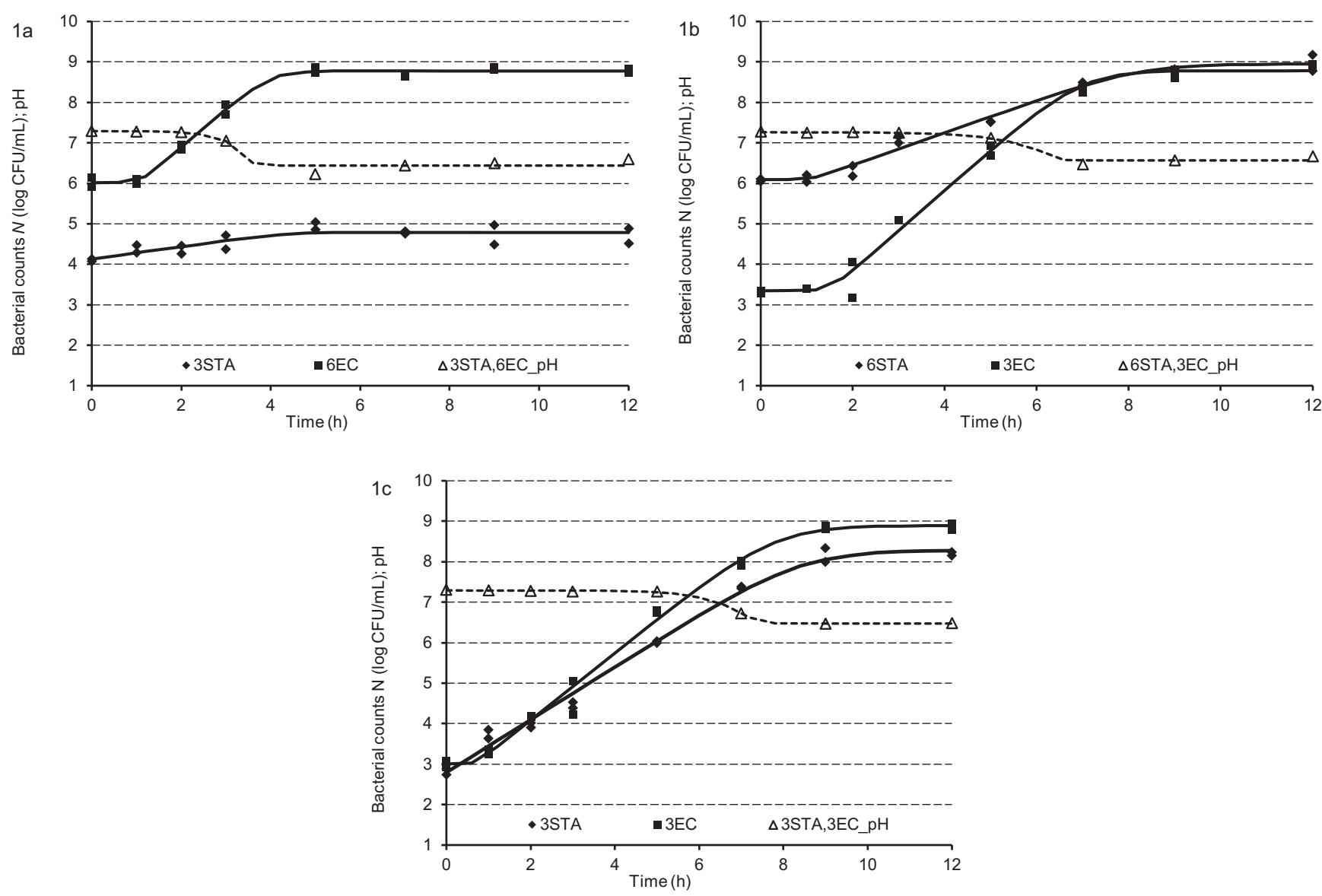

FIGURE 1. Growth of S. aureus 2064 and E. coli BR during co-cultivation in UHT milk in dependence on their initial counts (1a - 3STA+6EC; $1 \mathrm{~b}-$ $6 \mathrm{STA}+3 \mathrm{EC}, 1 \mathrm{c}-3 \mathrm{STA}+3 \mathrm{EC}$ ) and subsistent change of $\mathrm{pH}$ value at $37^{\circ} \mathrm{C}$.

growth curves at $37^{\circ} \mathrm{C}$ are depicted in Figure 1a-c, where one can see that if the initial concentration of E. coli and S. aureus was almost equal $(3 \mathrm{STA}+3 \mathrm{EC})$, both microorganisms grew very similarly to their typical final densities of about 8-9 $\log \mathrm{CFU} / \mathrm{mL}$. Also in the case of dominating $S$. aureus counts $(6 \mathrm{STA}+3 \mathrm{EC})$, the growth of $E$. coli was affected only by the incubation temperature and not by the presence of $S$. aureus, as it is expressed by statistically insignificant differences $(\mathrm{p} \geq 0.05)$ at $6,12,18$, and $37^{\circ} \mathrm{C}$ between growth rates of $E$. coli during co-culture with $S$. aureus in experiments $3 \mathrm{EC}+3 \mathrm{STA}$ and $3 \mathrm{EC}+6 \mathrm{STA}$ (missing superscript $\mathrm{b}$ in Table 1). Also in these experiments, E. coli was able to reach final densities in the stationary phase of at least $7 \mathrm{log}$ $\mathrm{CFU} / \mathrm{mL}$. However, when there was an excess of $E$. coli in the media $(3 \mathrm{STA}+6 \mathrm{EC})$, the growth of $S$. aureus was inhibited and resulted in significantly lower final counts of $S$. aureus. The maximal $S$. aureus counts in the stationary phase in the case of $E$. coli prevalence in the media were at densities lower than $5 \log \mathrm{CFU} / \mathrm{mL}$.

Based on co-cultivation growth of $S$. aureus and E. coli and based on comparing their mono-cultural growth [Medvedová \& Valík, 2012; Medvedová et al., 2018], it can be concluded that the $S$. aureus 2064 growth is inhibited in the presence of $E$. coli BR abundance. It can probably be due to faster nutrient consumption by E. coli and also to the production of metabolites with antistaphylococcal properties, e.g. lactic acid, citric acid, and other organic acids, lower fatty ac- ids. All these substances were identified in E. coli by Kim \& Kim [2017] who reported about 1000 intracellular metabolites in E. coli. Even so, the actual produced substances are dependent on completeness of the media and other factors affecting E. coli biosynthesis processes [Tokuyama et al., 2019], in the case of $E$. coli cultivation in milk, the completeness of media is unchallenged [Claeys et al., 2013; Hahne et al., 2019].

The intensiveness and dominance of $E$. coli growth is obvious also in Figure 2. Values of its specific growth rates were in all experiments and at all temperatures higher than the specific growth rates of $S$. aureus, as the linear curve of $E$. coli specific growth rates affected by temperature was above linear curve of $S$. aureus in experiments 3STA+3EC. We may suppose that $E$. coli started to grow earlier than $S$. aureus (majority of $E$. coli lag phases are shorter than those of $S$. aureus), subsequently it started to consume nutrients and produced metabolites. Taking together, we may assume that E. coli was more effective in nutrient competition and together with probable antistaphylococcal metabolites it led to $S$. aureus 2064 growth inhibition during their co-cultural growth.

The only exceptions of this trend were experiments at 6 and $12^{\circ} \mathrm{C}$. At $12^{\circ} \mathrm{C}$, and in the case of $3 \mathrm{STA}+6 \mathrm{EC}$ experiment, $S$. aureus reached in the stationary phase counts of $8.07 \log \mathrm{CFU} / \mathrm{mL}$. It may be a result of slower $\mathrm{pH}$ value decrease $(k=-0.031 / h)$ compared to its decrease at other temperatures, where the slowest decrease $(\mathrm{k}=-0.07 \mathrm{1} / \mathrm{h})$ was observed at $15^{\circ} \mathrm{C}$; even it was 2.3 -times faster. 


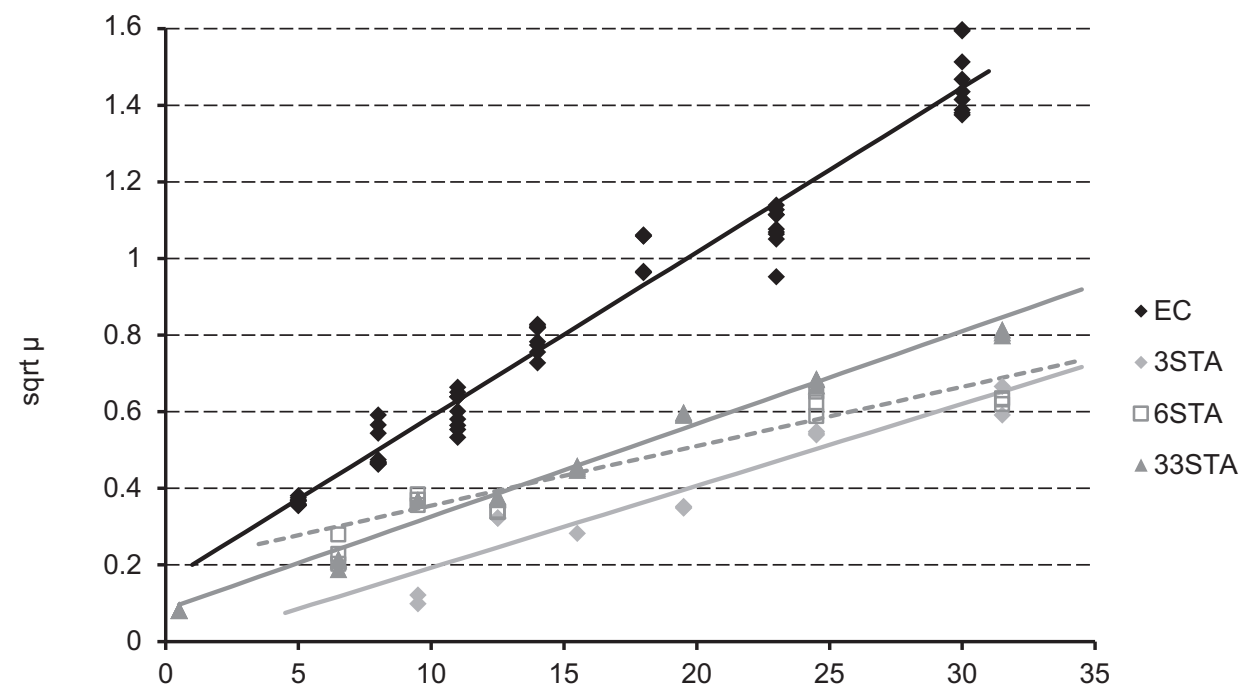

FIGURE 2. Effect of incubation temperature (expressed as $\mathrm{T}-\mathrm{T}_{\min }$ ) on the specific growth rate (expressed as square root of specific growth rate $\mu$ ) of $E$. coli (EC) BR in mono-culture ( $\bullet$ ) and during its co-cultivation with $S$. aureus (STA) 2064 in 3STA+3EC (•), in 6STA+3EC ( $\square)$ and 3STA+6EC ( $\bullet$ ) in UHT milk according to Ratkowsky model. 3STA or 3EC stands for initial bacterial density of $10^{3} \mathrm{CFU} / \mathrm{mL}, 6 \mathrm{STA}$ or $6 \mathrm{EC}$ stands for initial bacterial density of $10^{6} \mathrm{CFU} / \mathrm{mL}$.

A specific trend of bacterial behavior was observed also at $6^{\circ} \mathrm{C}$, since only rotting of $E$. coli was observed at all mutual initial counts combinations. Contrary, $S$. aureus was able either to maintain its counts $(6 \mathrm{STA}+3 \mathrm{EC})$ or even increase its counts by about $2.59 \log \mathrm{CFU} / \mathrm{mL}(3 \mathrm{STA}+3 \mathrm{EC})$ or increase them by about $0.9 \log \mathrm{CFU} / \mathrm{mL}$ in the first phase (marked with * in Table 1) and after the second lag phase lasting for $242 \mathrm{~h}$, the decrease of its counts was noticed with the rate of -0.01 $1 / \mathrm{h}$ (growth parameters from the second phase are not shown in Table 1). The ability of $S$. aureus to grow at $6^{\circ} \mathrm{C}$ in experiment $3 \mathrm{STA}+3 \mathrm{EC}$ with the specific growth rate of $\mu=0.021 / \mathrm{h}$ is remarkable, since in ultra-high temperature treated milk the same isolate was unable to grow at $6^{\circ} \mathrm{C}$ and it started to grow only at $7^{\circ} \mathrm{C}$ (with $\mu=0.0061 / \mathrm{h}$ ) [Medvedová \& Valík, 2012]. It is also worthy of mention that at $6^{\circ} \mathrm{C}$ the $S$. aureus isolate was able to maintain its counts in experiment $6 \mathrm{STA}+3 \mathrm{EC}$ at density of $6 \log \mathrm{CFU} / \mathrm{mL}$ for 36 days. It is undesirable in the case of enterotoxigenic strains as $5 \log \mathrm{CFU} / \mathrm{mL}$ are the minimal counts needed for staphylococcal enterotoxins production [Delbes et al., 2006; Charlier et al., 2008]. Therefore, it seems that the presence of $E$. coli helped $S$. aureus to withstand such a low temperature better that during its mono-cultural growth.

The effect of temperature on the microbial growth in suboptimal temperature range can be described by Ratkowsky model. As it is shown in Figure 2 and by equation 1 (Table 2), there was a linear trend in $E$. coli growth rate increase in dependence on temperature and it was not influenced by the presence of $S$. aureus. On the other hand, the growth rate of $S$. aureus was influenced not only by the incubation temperature but also by the presence of E. coli and mutual ratio between them (Figure 2). It is also obvious in Table 2, where 3 different equations describing the growth rate of $S$. aureus in dependence of $E$. coli initial counts are presented. an inevitable part of predictive modelling is also validation. Subsistent validation indices are also mentioned in Table 2. Since the discrepancy coefficient for the Ratkowsky model describing the growth of E. coli is only $16 \%$, it is also clear that its growth was influenced only by the incubation temperature. It is also emphasized by statistically insignificant discrepancies $(\mathrm{p} \geq 0.05)$ in almost all experiments between $E$. coli growth rates at different $S$. aureus initial counts and their combinations. Moreover, also in the case of E. coli lag phase there were only few cases when its values were significantly $(\mathrm{p} \geq 0.05)$ influenced by $S$. aureus initial density. It was also the case of E. coli final densities in the stationary phase. On the other hand, discrepancy indices of $23.9-43.9 \%$ are referring to a significant effect of $E$. coli presence in the cultivation media, mutual ratio between $E$. coli and $S$. aureus, and also to the effect

TABLE 2. Validation of Ratkowsky model describing the dependence of temperature on specific growth rate of E. coli BR and S. aureus 2064 during their mutual co-cultivation.

\begin{tabular}{l|c|c|c|c|c}
\hline Experimental variant & Equation describing dependence & $A_{\mathrm{f}}$ & $B_{\mathrm{f}}$ & $\% D_{\mathrm{f}}$ & $R^{2}$ \\
\hline 1: EC in all & $\sqrt{\mu}=0.028\left(T-T_{\min }\right)+0.104$ & 1.160 & 0.994 & 16.0 & 0.968 \\
2: STA in 3STA+3EC & $\sqrt{\mu}=0.036\left(T-T_{\min }\right)+0.133$ & 1.239 & 0.953 & 23.9 & 0.980 \\
3: STA in 3STA+6EC & $\sqrt{\mu}=0.021\left(T-T_{\min }\right)-0.021$ & 1.439 & 1.015 & 43.9 & 0.883 \\
4: STA in 6STA+3EC & $\sqrt{\mu}=0.024\left(T-T_{\min }\right)+0.259$ & 1.411 & 0.960 & 41.1 & 0.904 \\
\hline
\end{tabular}


of incubation temperature. Besides $S$. aureus specific growth rate, also its lag phase duration and also counts in the stationary phase were significantly influenced by the presence of the second bacterial population.

Regarding the $\mathrm{pH}$ value of the growth media, its value in all performed experiments started to decline from an average value of $7.40 \pm 0.11(n=96 ; c v=1.5 \%)$ after a given time (pH lag phase) that was as shorter as the incubation temperature was higher. The $\mathrm{pH}$ value decrease was observed during the growth phase of $E$. coli to an average value of $\mathrm{pH} 6.31 \pm 0.31 \quad(\mathrm{n}=96 ; \mathrm{cv}=5.0 \%)$. The lowest $\mathrm{pH}$ value observed in time of reaching the stationary phase by $E$. coli indicates that its growth was accompanied by the production of acid with subsequent $\mathrm{pH}$ value decrease. Contrary, in the case of slower $E$. coli growth (experiments with lower values of $E$. coli specific growth rates) also its metabolic activity was slower that indicates lower $\mathrm{pH}$ value decrease rates $k$ (Table 1). Finally, during the stationary phase of E. coli, the $\mathrm{pH}$ value started to increase again to a final value of about $6.62 \pm 0.33(\mathrm{n}=96 ; \mathrm{cv}=5.0 \%)$. As the $\mathrm{pH}$ value was determined only in one of parallels, the statistical analysis of $\mathrm{pH}$ value parameters was not performed.

\section{CONCLUSION}

To conclude, the interactions between two frequent contaminants of raw materials, E. coli and $S$. aureus, as affected by temperature and their mutual ratios were described. The growth of $E$. coli isolate was affected and positively stimulated by the incubation temperature. During its growth, $\mathrm{pH}$ value decrease was observed as a result of $E$. coli metabolic activity. $\mathrm{pH}$ decrease together with competition for nutrient led to $S$. aureus growth inhibition, even its growth was positively stimulated by increasing incubation temperature. Presented results may help during production of mainly foods with minimal heat treatment with the aim to increase their safety and harmlessness. However, as many lactic acid bacteria cultures are used in the food industry, their role in spoilage / pathogenic bacteria growth is indisputable; the problem of microbial behavior and interactions is more complex and need to be described deeply. Furthermore, mathematical modelling cannot be a compromise or alternative to the established hygiene norms. Using high quality raw material is crucial in dairy technology especially in "traditional ways of production using raw milk" to increase safety of those products

\section{RESEARCH FUNDINGS}

This work was supported by grant VEGA No. 1/0532/18.

\section{CONFLICT OF INTEREST}

None of the authors of this manuscript has a financial or personal relationship with other people or organizations that could inappropriately influence the content of this work.

\section{REFERENCES}

1. Ačai, P., Valík, L., Medved’ová, A., Rosskopf, F. (2016). Modelling and predicting the simultaneous growth of Escherichia coli and lactic acid bacteria in milk. Food Science and Technology International, 22(6), 475-484.

2. Baranyi, J., Roberts, T.A. (1994). A dynamic approach to predicting bacterial growth in food. International Journal of Food Microbiology, 23(3-4), 277-294.

3. Baranyi, J., Pin, C., Ross, T. (1999). Validating and comparing predictive models. International Journal of Food Microbiology, 48(3), 159-166.

4. Brocklehurst, T.F. (2004). Challenge of the food environment. In R.C., McKellar, X., Lu (Eds.), Modelling Microbial Responses in Food, CRC Press Inc., Boca Raton, Florida, USA, pp. 197-232.

5. Charlier, C., Even, S., Gautier, M., LeLoir, Y. (2008). Acidification is not involved in the early inhibition of Staphylococcus aureus growth by Lactococcus lactis in milk. International Dairy Journal, 18(2), 197-203.

6. Claeys, L.W., Cardoen, S., Daube, G., De Block, J., Dewettinck, K., Dierick, K., De Zutter, L., Huyghebaert, A., Imberechts, H., Thiange, P., Vandenplas, Y., Herman, L. (2013). Raw or heated cow milk consumption: Review of risks and benefits. Food Control, 31, 251-262.

7. Delbes, C., Alomar, J., Chougui, N., Martin, J.-F., Montel, M.Ch. (2006). Staphylococcus aureus growth and enterotoxin production during manufacture of cooked, semihard cheese from cows' milk. Journal of Food Protection, 69(9), 2161-2167.

8. Giménez, B., Dalgaard, P. (2004). Modelling and predicting the simultaneous growth of Listeria monocytogenes and spoilage microorganisms in cold-smoked salmon. Journal of Applied Microbiology, 96(1), 96-109.

9. Hahne, J., Isele, D., Berning, J., Lipski, A. (2019). The contribution of fast growing, psychrotrophic microorganisms on biodiversity of refrigerated raw cow's milk with high bacterial counts and their food spoilage potential. Food Microbiology, 79, 11-19.

10. ISO 4833-1:2013. Microbiology of the food chain - Horizontal method for the enumeration of microorganisms - Part 1: Colony count at 30 degrees $\mathrm{C}$ by the pour plate technique. ICS: 07.100 .30 (2013), p. 9.

11. Kim, J., Kim, K.H. (2017). Effects of minimal media vs. complex media on the metabolite profiles of Escherichia coli and Saccharomyces cerevisiae. Process Biochemistry, 57, 64-71.

12. Medvedová, A., Rosskopf, F., Liptáková, D., Valík, L. (2018). Prediction of temperature effect on growth of two raw milk cheese isolates of Escherichia coli in milk. Journal of Food Nutrition and Research, 57(2), 141-150.

13. Medvedová, A., Valík, L. (2012). Staphylococcus aureus: Characterisation and quantitative growth description in milk and artisanal raw milk cheese production. In A. Eissa (Ed.), Structure and Function of Food Engineering, InTech, Rijeka, Croatia, pp. 71-102.

14. Medvedová, A., Valík, L., Studeničová, A. (2009). The effect of temperature and $a_{\mathrm{w}}$ on the growth of Staphylococcus aureus. Czech Journal of Food Sciences, 27, SI2, 28-35.

15. National Standard Method F23 (2005). Enumeration of Enterobacteriaceae by the Colony Count Technique, Standards Unit, 
Evaluations and Standards Laboratory, Health Protection Agency, p. 23.

16. Quigley, L., O'Sullivan, O., Stanton, C., Beresford, T.B., Ross, R.P., Fitzgerald, G.F., Cotter, P.D. (2013). The complex microbiota of raw milk. FEMS Microbiology Letters, 37(5), 664-698.

17. Quigley, L., O’Sullivan, O., Beresford, T.B., Ross, R.P., Fitzgerald, G.F., Cotter, P.D. (2011). Molecular approaches to analysing the microbial composition of raw milk and raw milk cheese. International Journal of Food Microbiology, 150(2-3), 81-94.

18. Ratkowsky, D.A., Olley, J., McMeekin, T.A., Ball, A. (1982). Relationship between temperature and growth rates of bacterial cultures. Journal of Bacteriology, 149(1), 1-5.

19. Ross, T., McMeekin, T.A. (1994). Predictive microbiology, review paper. International Journal of Applied Microbiology, 81, 501-508.

20. Tokuyama, K., Toya, Y., Matsuda, F., Cress, B.F., Koffas, M.A.G., Shimizu, H. (2019). Magnesium starvation improves production of malonyl-CoA-derived metabolites in Escherichia coli. Metbabolic Engineering, 52, 215-223.
21. Valík, L'. (2013). Risk assessment of pathogenic bacteria presence in raw milk. [http://www.mpsr.sk/sk/index.php?navID=525\&nav ID2=525\&sID=111\&id=8134\&start]. Accessed 10 May, 2019 .

22. Valík, L'., Ačai, P. (2016). Predictive microbiology and microbiological risk assessment (in Slovak). Publisher STU, Bratislava, Slovakia, p. 160.

23. Valík, L., Ačai, P., Medvedová, A. (2018). Application of competitive models in predicting the simultaneous growth of Staphylococcus aureus and lactic acid bacteria in milk. Food Control, 87, 145-152.

24. Vereecken, K.M., Dens, E.J., Van Impe, J.F. (2000). Predictive modelling of mixed microbial populations in food products: evaluation of two-species models. Journal of Theoretical Biology, 205(1), 53-72.

Submitted: 17 July 2019. Revised: 9 December 2020. Accepted: 7 January 2020. Published on-line: 02 March 2020. 